\begin{tabular}{|c|c|c|c|}
\hline Article Info & REVIEW ARTICLE & DERLEME MAKALESİ & \\
\hline Title of Article & \multicolumn{2}{|c|}{$\begin{array}{l}\text { The Effect of Landscape Design on Security } \\
\text { Perception and Fear of Crime in Sanlıurfa } \\
\text { AMATEM and CEMATEM Campus }\end{array}$} & \\
\hline $\begin{array}{l}\text { Corresponding } \\
\text { Author }\end{array}$ & \multicolumn{2}{|c|}{$\begin{array}{l}\text { Filiz ÇELİK } \\
\text { Selçuk Üniversitesi, Mimarlık ve Tasarım Fakültesi, Peyzaj Mimarlığı Bölümü, } \\
\text { filiz@selcuk.edu.tr }\end{array}$} & \\
\hline $\begin{array}{l}\text { Received Date } \\
\text { Accepted Date }\end{array}$ & \multicolumn{2}{|c|}{$\begin{array}{l}26.08 .2021 \\
10.09 .2021\end{array}$} & \\
\hline DOI Number & \multicolumn{2}{|l|}{ https://doi.org/10.35674/kent.987434 } & \\
\hline Author / Authors & $\begin{array}{l}\text { Filiz ÇELIK } \\
\text { Meryem SARIKAYA }\end{array}$ & $\begin{array}{l}\text { ORCID: 0000-0002-4006-5947 } \\
\text { ORCID: 0000-0001-6789-975X }\end{array}$ & \\
\hline How to Cite & \multicolumn{2}{|c|}{$\begin{array}{l}\text { Çelik, F. ve Sarıkaya, M. (2021). Şanlıurfa AMATEM ve ÇEMATEM Kampüsünde } \\
\text { Peyzaj Tasarımının Güvenlik Algısı ve Suç Korkusuna Etkisi, Kent Akademisi, Volume, } \\
\text { 14, Issue 3, Pages, 644-658 }\end{array}$} & $\begin{array}{l}\text { Kent Akademisi } \\
\text { Urban Academy }\end{array}$ \\
\hline
\end{tabular}

\title{
Şanlıurfa AMATEM ve ÇEMATEM Kampüsünde Peyzaj Tasarımının Güvenlik Algısı ve Suç Korkusuna Etkisi
}

Filiz ÇELİK ${ }^{1}$

\begin{abstract}
:
Despite all the precautions, alcohol and substance use is increasing rapidly both in Turkey and in the world. The centers needed for the treatment and rehabilitation of individuals using alcohol and substances in Turkey are put into service in many cities by the Ministry of Health as AMATEM (Alcohol and Substance Addiction Research, Treatment and Training Center) and ÇEMATEM (Child and Adolescent Substance Addiction Treatment Center). Although AMATEM and ÇEMATEM centers are rehabilitation centers, they are places where fear of crime and security concerns are felt intensely due to the patients they serve. The aim of this study is to determine the effects of landscape design applied in Şanlıurfa AMATEM and ÇEMATEM campuses on the perception of security and fear of crime. Because violence and crime tendencies can be seen in patients who are treated for alcohol and substance use, which creates a perception of insecurity. For this reason, AMATEM and ÇEMATEM campuses are becoming places where the need for security and fear of crime increase for patients and staff. For this purpose, landscape projects and applications were examined; Suggestions that will positively increase the perception of security and reduce the fear of crime for the AMATEM and ÇEMATEM campuses are included.
\end{abstract}

KEYWORDS: AMATEM, ÇEMATEM, landscape design, security perception, fear of crime.

\footnotetext{
${ }^{1}$ Selçuk Üniversitesi, Mimarlık ve Tasarım Fakültesi, Peyzaj Mimarlığı Bölümü, filliz@selcuk.edu.tr

${ }^{2}$ Selçuk Üniversitesi, Fen Bilimleri Enstitüsü, Peyzaj Mimarlığı ABD Doktora Öğrencisi,

Sağlık Bakanlığı, Sağlık Yatırımları Genel Müdürlüğü, Etüd Proje ve Emlak Daire Başkanlığı, Peyzaj Birim Sorumlusu,

meryemsarikaya@hotmail.com
} 


\section{ÖZ:}

Tüm önlemlere rağmen hem Türkiye hem de Dünya'da alkol ve madde kullanımı hızla artmaktadır. Türkiye'de alkol ve madde kullanan bireylerin tedavisi ve rehabilitasyonu için ihtiyaç duyulan merkezler, AMATEM (Alkol ve Madde Bağımlılığı Araştırma, Tedavi ve Eğitim Merkezi) ve ÇEMATEM (Çocuk ve Ergen Madde Bağımlılığı Tedavi Merkezi) olarak Sağlık Bakanlığı tarafından pek çok kentte hizmete sunulmaktadır. AMATEM ve ÇEMATEM merkezleri her ne kadar rehabilitasyon merkezi olsa da hizmet ettiği hastalar nedeniyle suç korkusu ve güvenlik kaygısının yoğun hissedildiği mekânlardır. Bu çalışmanın amacı, Şanlıurfa AMATEM ve ÇEMATEM kampüslerinde uygulanan peyzaj tasarımının güvenlik algısı ve suç korkusuna etkilerini belirlemektir. Çünkü alkol ve madde kullanımı nedeniyle tedavi gören hastalarda şiddet ve suç eğilimi görülebilmekte bu durum ise güvensizlik algısı yaratmaktadır. Bu nedenle AMATEM ve ÇEMATEM kampüsleri, hastalar ve çalışanlar için güvenlik ihtiyacı ve suç korkusunun arttığ yerler haline gelmektedir. Bu amaçla peyzaj projeleri ve yapılan uygulamalar incelenmiş; AMATEM ve ÇEMATEM kampüsleri için güvenlik algısını olumlu yönde arttıracak ve suç korkusunu azaltacak önerilere yer verilmiştir.

ANAHTAR KELIMELER: AMATEM, ÇEMATEM, güvenlik algısı, suç korkusu, peyzaj tasarımı.

\section{GíRIŞ:}

Tüm önlemlere rağmen hem Türkiye hem de Dünya'da alkol ve madde kullanımı giderek yaygınlaşmakta ve buna bağlı olarak ortaya çıkan bağımlılık hızla artmaktadır. Alkol ve madde kullanımı ve bağımlılığı, çok yönlü artarken hem kullanıcı ve satıcı sayısı hem de piyasaya sürülen madde oranı da artmakta ancak başlama yaşı düşmektedir (Anonim, 2018; Yoldaş ve Demircioğlu, 2020; Karataş, 2021).

Bağımlılık, bireyin kullandığı bir obje veya gerçekleştirdiği bir eylem üzerinde kontrolü kaybetmesi ve onsuz yaşamını sürdürmekte zorlanmaya başlaması olarak tanımlanabilir. Bireyleri fiziksel, zihinsel, ruhsal ve sosyal açıdan ciddi şekilde etkileyen bir problem olarak bağımlılık aynı zamanda toplum içinde en büyük tehditlerden birisidir. Bağımlılıklar, sağlık üzerindeki olumsuz etkilerinin yanı sıra şiddet, istismar, maddi sorunlar, aile ve toplum huzurunun bozulması gibi sorunlara neden olmaktadır. Ayrıca bağımlılıklar bireylerin suça yönelmesine sebep olurken, toplumda güvensizlik algısına, toplumsal huzur ve düzenin bozulmasına, çevre kirliliğine ve ekonomik kayıplara yol açmaktadır. Bağımlı bireyin madde arayışı ve bağımlılık sonrası tedavi süreci, iş gücü kaybına neden olurken sağlık, sosyal güvenlik, adalet ve ceza sistemleri üzerindeki finansman ve iş yükünü de arttırmaktadır. Bağımlılıklar, "madde bağımlılı̆̆ı" ve "davranışsal bağımlılıklar" olarak ele alınabilir. "Madde bağımlılı̆̆ı" kapsamında tütün, alkol, uyuşturucu madde bağımlılığı; "davranışsal bağımlılıklar" kapsamında ise teknoloji bağımlılı̆̆ 1 ve teknoloji bağımlılı̆g ile ilgili olan internet, dijital oyun, sosyal medya, kumar, alış-veriş ve akıllı telefon bağımlılığı yer almaktadır (Anonim, 2018). Madde bağımlılığının tedavisi, tıbbi acil yardımla başlayıp ilaç tedavisi, psiko-sosyal müdahale ve rehabilitasyonla devam etmektedir. Bu kapsamda Türkiye'de ayaktan veya yatarak madde bağımlılığı tedavisi gerçekleştiren merkezler bulunmaktadır (Karataş, 2021).

Türkiye'de alkol ve madde kullanan bireylerin tedavisi ve rehabilitasyonu için ihtiyaç duyulan merkezler, AMATEM (Alkol ve Madde Bağımlılığı Araştırma, Tedavi ve Eğitim Merkezi) ve ÇEMATEM (Çocuk ve Ergen Madde Bağımlılığı Tedavi Merkezi) olarak Sağlık Bakanlığı tarafından pek çok kentte hizmete sunulmaktadır. AMATEM ve ÇEMATEM her ne kadar rehabilitasyon merkezi olsa da hizmet ettiği hastalar nedeniyle suç korkusu ve güvenlik kaygısının yoğun hissedildiği mekânlardır. Bu merkezlerde hem yetişkin hastalar ile çocuk ve ergen hastaları birbirinden korumak hem de tüm hasta gruplarından sağlık çalışanlarını korumak önem arz etmektedir. Çünkü alkol ve madde kullanımı nedeniyle tedavi gören hastalarda şiddet ve suç eğilimi görülebilmekte bu durum ise güvensizlik algısı yaratmaktadır.

1315 sayılı Yataklı Tedavi Kurumları İşletme Yönetmeliği’nde "güvenlik hizmetleri” ile ilgili Madde 177'de "sağlık kurumlarında güvenlik hizmetleri, kendi bünyesinde kurulan güvenlik birimi veya hizmet alımı yoluyla ilgili mevzuata göre kurulan özel güvenlik kuruluşlarına gördürülebilir" şeklinde tanımlanmıştır (Anonim, 1982). 30710 sayılı Bağımlılık Danışma, Arındırma ve Rehabilitasyon Merkezleri Hakkında Yönetmelik'te ise Madde 9'da "merkezler, çalışanların ve hizmet alanların güvenliğini tehdit edebilecek risklere karşı gerekli güvenlik tedbirlerini alır" ifadesi yer almaktadır (Anonim, 2019). Yönetmeliklerde güvenliğin sağlanması, bina içindeki birimler için açıklanmış ancak açık alanlarda güvenliğin sağlanması ve suçun önlenmesi geri planda kalmıştır. AMATEM ve ÇEMATEM kampüslerinde 
güvenliğin sağlanması ve suçun önlenmesi, güvenlik hizmetlerinin yanı sıra peyzaj tasarımı, uygulama, yönetim, bakım ve kullanıcı katılımını içeren bütüncül bir yaklaşım gerektirmektedir. AMATEM ve ÇEMATEM kampüsleri hem tedavi gören hastalar ve hasta yakınları hem de çalışan personel için güvenli ve suç korkusundan emin mekânsal özelliklere sahip olmalıdır.

Bu çalışmanın amacı, Şanlıurfa AMATEM ve ÇEMATEM kampüslerinde uygulanan peyzaj tasarımının güvenlik algısı ve suç korkusu üzerine etkilerini belirlemektir. Bu amaçla peyzaj projeleri ve yapılan uygulamalar incelenmiş; AMATEM ve ÇEMATEM kampüsleri için güvenlik algısını olumlu yönde arttıracak ve suç korkusunu azaltacak önerilere yer verilmiştir.

\section{ALKOL VE MADDE KULLANIMI İLE SUÇ İLISŞKISİ VE GÜVENLİK ALGISI:}

Suç, geleneksel norm ve değerlere uygun olmayan davranışlarda bulunma ve bu davranışların yıkıcı nitelik taşıması nedeni ile toplumsal yapıya yönelen bir tehdittir (Giddens and Sutton, 2019). Suç korkusu ise suçun toplum içinde yarattığı güvensizlik algısı olarak ifade edilebilir (Dolu vd., 2010). Suç ve suç korkusu, aynı mekânı kullanan insanlarda güvensizlik algısı yaratmaktadır (Karakaya, 2015). Bireyler içinde bulundukları her ortamda güven içinde ve suç korkusundan uzak yaşayabilmelidir. Suç korkusunun ortadan kaldırılması veya kontrol edilmesi, güvenlik algısının ve buna paralel olarak yaşam kalitesinin arttıılması bakımından büyük önem taşımaktadır (Çelik ve Mirza, 2020).

Alkol ve madde kullanımı ile uyuşturucu madde satışı, suç korkusu ve güvensizlik algısını tetikleyen faktörler arasında yer almaktadır. Kentlerde güvenlik algısı ve suç korkusu ile ilgili yapılan çalışmalarda özellikle de kamuya açık alanlarda (park ve bahçelerde), sosyal ve fiziki düzen bozukluklarının göstergesi olan düşük gelir, yoksulluk, yaş, cinsiyet, alkol ve madde kullanımı ve satışı, şüpheli ve yabancıların bulunması, sokak aydınlatmalarının yetersiz olması, terk edilmiş ve yıkık binaların varlığı önemli faktörler arasında belirtilmiştir (Çelik, 2018; Özaşçılar ve Ziyalar, 2009; Uludağ, 2010). Günümüzde dünya genelinde kamusal alanlarda güvenlik seviyelerinin iyileştirilmesi ve suç korkusunun azaltılması yöneticiler, plancılar ve kentsel tasarımcılar için en önemli konulardan biri olarak görülmektedir. Güvenlik kaygıları, neredeyse tüm kentsel açık-yeşil alanlar için geçerlidir. Suçu önleme ve güvenlik algısını pozitif yönde etkileme amaçlı yapılan çalışmaların büyük bölümü, çevre düzenlemesi ve bakımın suçu önlemede ve güvenlik algısını arttırmada etkili olduğunu vurgulamaktadır (Çelik, 2018).

Bireyleri suç işlemeye yönelten birçok faktör bulunmakta; alkol ve uyuşturucu madde kullanımı-bağımlılı̆̆ da bu faktörler arasında yer almaktadır. Alkol ve madde kullanımı tek başına bir suç türü olmamakta, pek çok suç türünün de temelini oluşturabilmektedir (Karatoprak ve Uzun, 2020). Alkol ve madde kullanan bireyler şiddet, saldırı, yaralama, cinayet, şantaj ve tehdit, taciz ve tecavüz, sahtekârlık ve hırsızlık gibi suç türlerinin yanı sıra kendine zarar verme, trafik kazaları ve iş kazalarına da neden olabilmektedir. Bu bireylerde hapis cezası veya tedavi sırasında da şiddet ve suç işleme eylemlerini sürdürme eğilimi görülebilmektedir (Karakartal, 2020).

Alkol ve madde kullanımının suç ile olan ilişkisini araştıran çalışmalarda, alkol ve madde kullanımının birçok aşamasında gerçekleşen, vücudun zarar görmesi, çekilme, alkol ve madde alımı sonrası gelişen psikoz ve paranoya gelişmesi gibi durumlar şiddet içerikli suç davranışları ile ilişsilendirilmektedir. Yapılan çalışmalarda, alkol ve madde kullanımı ile saldırganlık ve şiddet eylemlerinin birbirini tetiklediği ortaya koyulmuştur. Uyuşturucu maddeler, kimyasal etkileri nedeni ile kullananlarda saldırgan davranışların, şiddet eylemlerinin ortaya çıkmasına neden olabilmekte ve böylece bireyleri kural tanımama, kendine ve çevreye zarar verme gibi davranışlara sürükleyebilmektedir. Haggård-Grann ve arkadaşlarının (2006), alkol ve madde kullanımının suç davranışını nasıl tetiklediğini araştırdıkları bir çalışmada, alkolün suç davranışına sürükleme etkisinin daha yüksek olduğunu belirlemişlerdir (Arabacı ve ark., 2017).

Alkol ve madde kullanımı ile suç davranışı arasındaki ilişkiyi inceleyen çalışmalarda çift yönlü bir ilişkinin olabileceği belirtilmektedir (Karatoprak ve Uzun, 2020). Bazı çalışmalarda, suça sürüklenme durumunun alkol ve madde kullanımını tetikleyebileceği de ileri sürülmektedir. Bu çalışmalarda, suç dünyası içerisinde bulunanların alkol ve madde kullanılan ortamlarla ve alt kültürlerle iletişiminin daha fazla olması nedeniyle suç işlemenin alkol ve madde kullanımına sebep olabileceği düşünülmektedir. Bu iki farklı yaklaşıma karşın, son yıllarda bazı çalışma bulguları da güçlü bir şekilde, madde ve suç ilişkinin sebep ve sonuç değil, eş zamanlı olarak birlikte görülen davranış bozuklukları olduğuna işaret etmektedir (Arabacı ve ark., 2017). 


\section{AMATEM VE ÇEMATEM:}

Türkiye'de alkol ve madde bağımlılarına yönelik tedavi hizmetleri, Sağlık Bakanlığı'na bağlı merkezler ile özel merkezlerde verilmektedir. AMATEM ve ÇEMATEM, Sağlık Bakanlığı tarafından pek çok kentte hizmete sunulmuştur. Türkiye'de kamu hastanelerinde 732 yatak kapasitesi ile 28 merkezde AMATEM hizmet verirken ÇEMATEM ise 7 merkezde 100 yatak kapasitesi ile faaliyetlerini sürdürmektedir. Türkiye'de alkol ve madde kullanan sayısı arttıkça, tedavi için gereken AMATEM ve ÇEMATEM merkezlerine olan ihtiyaç da artmaktadır. Bu nedenle T.C. Sağlık Bakanlığı, Sağlık Yatırımları Genel Müdürlüğ̈̈, 2021 yılı sonuna kadar 17 ilde 30 adet yatırım (Tablo 1) gerçekleştirerek toplam 924 yatak kapasitesine ulaşmayı hedeflemektedir (Anonim, 2021).

Tablo1. AMATEM ve ÇEMATEM planlanan iller (Anonim, 2021)

\begin{tabular}{l|c|lc}
\hline \multicolumn{2}{c|}{ AMATEM } & \multicolumn{2}{c}{ ÇEMATEM } \\
\hline Planlanan il & Yatak kapasitesi & Planlanan il & Yatak kapasitesi \\
\hline Antalya & 20 & Adana & 15 \\
\hline Aydın & 30 & Ankara & 15 \\
\hline Bitlis & 20 & Antalya & 10 \\
\hline Çanakkale & 30 & Bitlis & 15 \\
\hline Diyarbakir & 30 & Diyarbakır & 15 \\
\hline Edirne & 30 & İstanbul (Anadolu) & 15 \\
\hline Eskişehir & 30 & Kocaeli & 15 \\
\hline Hatay & 30 & Konya & 15 \\
\hline İstanbul (Anadolu) & 50 & Manisa & 15 \\
\hline İstanbul (Anadolu) & 100 & Sakarya & 20 \\
\hline İstanbul (Avrupa) & 50 & Şanliurfa & $\mathbf{1 8 5}$ \\
\hline Kahramanmaraş & 19 & Van & \\
\hline Kocaeli & 50 & Toplam & \\
\hline Konya & 60 & & \\
\hline Manisa & 100 & & \\
\hline Sakarya & 30 & & \\
\hline Şanliurfa & 30 & & \\
\hline Van & 30 & Genel toplam & \\
\hline Toplam & $\mathbf{7 3 9}$ & & \\
\hline
\end{tabular}

Türkiye'de uyuşturucu tedavisi genellikle hastanelerde yapılmaktadır. Ancak uyuşturucu tedavisi farklı ve özel bir tedavi biçimi olduğu için diğer hastalarla birlikte aynı bina içinde bu tedavinin yapılması sadece diğer branşlardan hastalar için değil, uyuşturucu bağımlıları için de hoş bir ortam yaratmamaktır. Bu nedenle uyuşturucu bağımlılarına çok özel tedavi biçimleri uygulayan birimler hastanelere bağlı olmakla birlikte ayrı mekânlarda kendi bağımsız uygulamalarını yapmaktadırlar (Tomanbay, 2016).

Türkiye'de ilk AMATEM, 1983 yılında, Bakırköy Ruh Sağlığı ve Sinir Hastalıkları Eğitim ve Araştırma Hastanesi kapsamında, ayrı binada bulunan bir servis olarak kurulmuştur (Anonim, 2021a). İstanbul Ord. Prof. Dr. Mazhar Osman Bakırköy Ruh Sağlığı ve Hastalıkları Eğitim ve Araştırma Hastanesi bünyesinde uçucu madde kullanan çocuklara yönelik olarak 1995 yılında UMATEM (Uçucu Madde Bağımlıları Araştırma ve Tedavi Merkezi) adında bir tedavi merkezi açılmıştır. UMATEM'in ismi 2007 yılında ÇEMATEM olarak değiştirilmiş ve Türkiye'de çocuk ve gençler için açılan ilk ÇEMATEM olarak kabul edilmektedir (Tomanbay, 2016).

AMATEM ve ÇEMATEM, alkol ve madde kullanımı ve bağımlılığını sonlandırma, bireylerin yaşamları üzerindeki kontrollerini yeniden ellerine alma ve kayıplarını kazandırma yönünde destek sunmaktadır. AMATEM ve ÇEMATEM'de öncelikle yoğun arındırma tedavileri, sonrasında ise psikoterapi servislerinde 14 veya 28 günlük ruhsal tedavi programı uygulanmaktadır. Hastalar, merkezlerde yatarak tedavisini tamamladıktan sonra bireysel veya grup şeklinde tedavilerine devam edilmektedir. Bunlara ek olarak AMATEM ve ÇEMATEM merkezleri; 
- Eğitim birimi olarak işlevini sürdürmektedir.

- Önleme ve eğitim programları hazırlamaktadır. Konferanslar, kitapçıklar, afiş ve broşürler ile önleme çalışmaları yapmaktadır. AMATEM tarafindan yetiştirilmiş rehber öğretmenlerle okullarda öğrencilere ve diğer öğretmenlere önleme çalışmaları devam ederken aynı zamanda ailelere ve hekimlere yönelik eğitimler de yer almaktadır.

- Bilimsel çalışmaların yürütüldüğü araştırma merkezleridir. Araştırma sonuçları, alkol ve madde kullanımı ve bağımlılığı alanındaki yerli ve yabancı dergilerde yayınlanmaktadır.

- Diğer merkezlerle ortak araştırmalar yürütülmektedir.

- Aile sorunlarının çözümü, mesleki eğitim ve sosyal beceriler kazandırma açısından düzenli grup ve bireysel terapiler verilmektedir (Anonim, 2018).

\section{ŞANLIURFA AMATEM VE ÇEMATEM KAMPÜSÜ:}

Şanlıurfa AMATEM ve ÇEMATEM, kent merkezinin güneyinde, merkez ilçe Eyyubiye İlçesi sınırları içinde yer almaktadır (Şekil 1). AMATEM ve ÇEMATEM Kampüsü toplam $32.524 \mathrm{~m}^{2}$ alana sahiptir. Aynı kampüste yer alan AMATEM 30 yataklı, ÇEMATEM ise 15 yatak kapasitelidir.

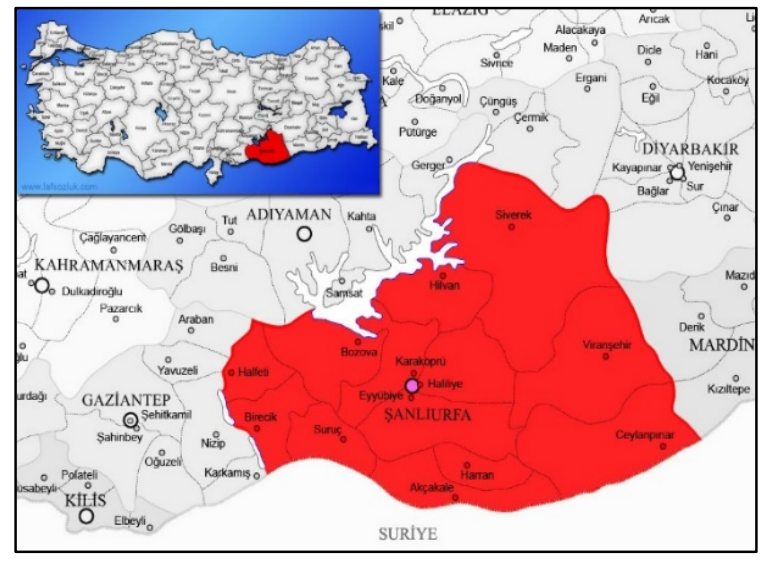

Şekil 1. Şanlıurfa AMATEM ve ÇEMATEM Kampüsü’nün konumu

Sağlık Bakanlığı, Sağlık Yatırımları Genel Müdürlüğü tarafindan 2018 yılı içerisinde Şanlıurfa AMATEM ve ÇEMATEM projelerinin ihalesi yapılmıştır. 17 Ekim 2018 tarihinde yapım sözleşmesi yapılarak kasım ayında inşaata başlanmıştır. İnşaat ve peyzaj çalışmaları, 28 Temmuz 2020 tarihinde tamamlanmış ve merkezler 17 Mart 2021 tarihinden itibaren hizmet vermeye başlamıştır.

30710 sayılı Bağımlılık Danışma, Arındırma ve Rehabilitasyon Merkezleri Hakkında Yönetmelik'te belirtilen şartlar doğrultusunda Şanlıurfa AMATEM ve ÇEMATEM binalarında muayene odası, rehabilitasyon odası, hasta odaları, bekleme salonu, laboratuvarlar, aktivite odaları ve yaşam alanı mevcuttur. Binalar, tip proje şeklinde hazırlanmış olup zemin kat ve 1. kattan oluşmaktadır (Tablo 2). Alana simetrik yerleştirilen binalar, dış cephe ve kütlesel olarak aynı olup iç mekândaki birimlerde farklılıklar vardır (Şekil 2).

Tablo 2. AMATEM ve ÇEMATEM binaları içerinde yer alan birimler (Uygun, 2018)

\begin{tabular}{l|l}
\hline \multicolumn{1}{c}{ Zemin Kat } & \\
\hline \multicolumn{1}{c}{ AMATEM ve ÇEMATEM binaları } \\
\hline Poliklinik odası (4 adet) & Kütüphane \\
\hline Psikolog odası & Psikolog odası \\
\hline Kontrollü idrar alma ünitesi & Bay, bayan detoks odası \\
\hline Özel Görüşme Odası (8 adet) & Özel görüşme odası \\
\hline Laboratuvar & Grup terapi odası \\
\hline Kan alma ünitesi & İlaç hazırlama ve hemşire istasyonu \\
\hline
\end{tabular}

The Effect of Landscape Design on Security Perception and Fear of Crime in Şanlıurfa AMATEM and CEMATEM Campus 


\begin{tabular}{l|l}
\hline Sosyal çalışma odası & Sosyal çalışmacı odası \\
\hline Heyet odası & 1 kişilik hasta odası (AMATEM'de 20 adet) \\
\hline Ziyaret odası & 1 kişilik hasta odası (ÇEMATEM'de 10 adet) \\
\hline Seminer odası (26 kişilik) & 2 Kişilik hasta odası (AMATEM'de 10 adet) \\
\hline Uğraş odası (resim) & 2 Kişilik hasta odası (ÇEMATEM'de 5 adet) \\
\hline Uğraş odası (müzik) & Yemekhane ve gündüz odası \\
\hline Uğraş odası (ahşap işleri) & Mutfak \\
\hline Spor salonu & Hemşire odası \\
\hline İdari ve teknik ofisler & Teknik ve temizlik odası \\
\hline Sorumlu doktor odası & Nöbetçi doktor odası \\
\hline Personel ve hasta WC & Çok amaçlı teras \\
\hline
\end{tabular}

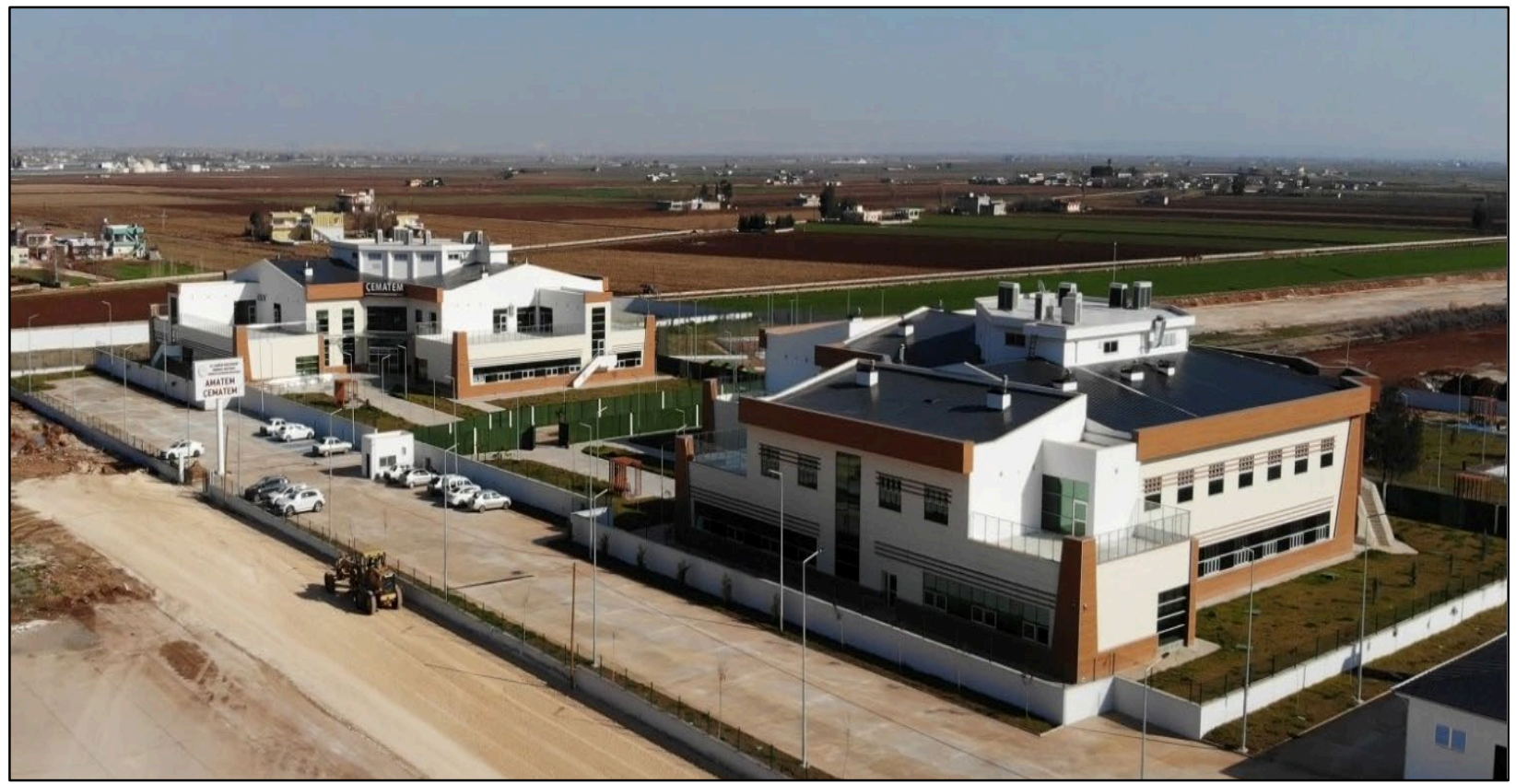

Şekil 2. AMATEM ve ÇEMATEM binası (Orijinal, 2021)

Bina dışında kalan açık alanlarda ise her iki merkez tarafından ortak kullanılan açık alanlar bulunmaktadır. Ön bahçe, $1.520 \mathrm{~m}^{2}$, arka bahçe ise $21.269 \mathrm{~m}^{2}$ alana sahiptir. AMATEM ve ÇEMATEM Kampüsü peyzaj tasarımında;

- Giriş-çıkışlar (Şekil 3),

- 110 araçlik otopark (104+6 adet engelli otoparkı),

- Sınırlayıcı duvar (dış duvar) ve ayırıcı duvar (iç duvar) (ayırıcı duvarlar sonradan eklenmiştir) (Şekil 4)

- Spor alanları (voleybol ve basketbol sahası, yürüyüş ve koşu yolu, bisiklet yolu, kum havuzu, atlama havuzu, 9 adet spor aleti) (Şekil 5),

- Yer satrancı (Şekil 5),

- 7 adet oturma grubu ve 5 adet piknik masasının yer aldığı oturma alanı (Şekil 5),

- Pek çok aktivitenin aynı anda yapılabileceği $15.446 \mathrm{~m}^{2}$ büyüklükte çim alan,

- Çocuklar için bağımsız oyun elemanları ve oyun grubu (1 oyun seti, 2 salıncak, 2 tahterevalli)

- $1.100 \mathrm{~m}^{2}$ alan üzerinde konumlandırılan hobi bahçeleri bulunmaktadır. 

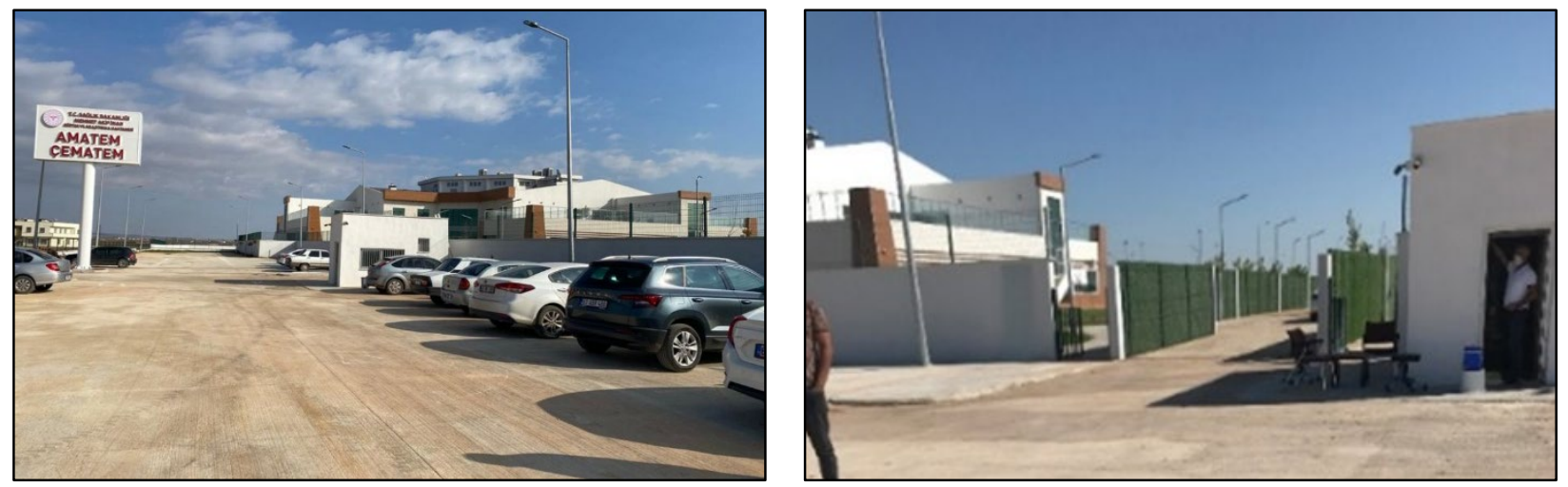

Şekil 3. Ana giriş ve otoparktan kampüs alanına giriş (Orijinal, 2019)
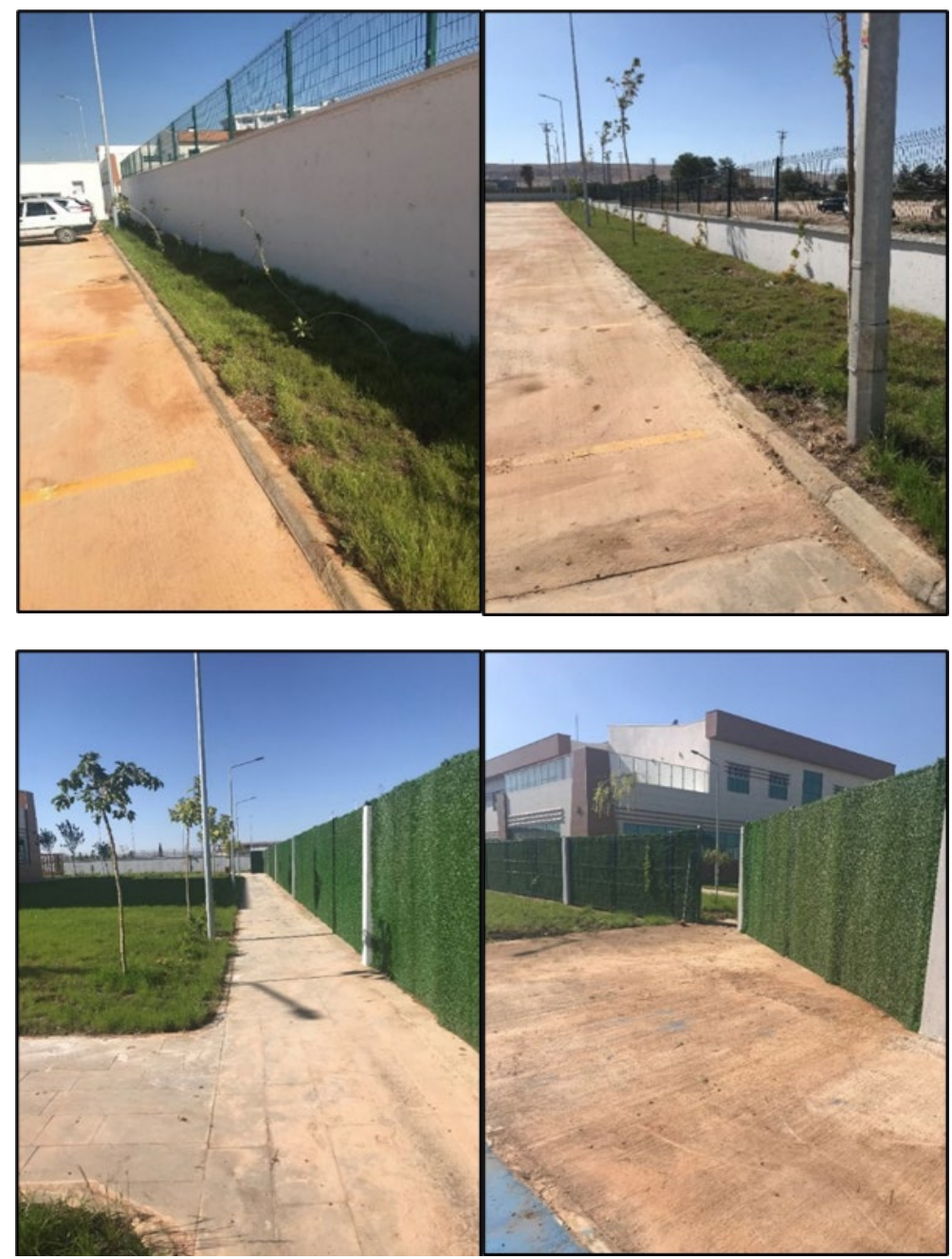

Şekil 4. Sınırlayıcı duvar (dış duvar) ve ayırıcı duvar (iç duvar) (Orijinal, 2019) 


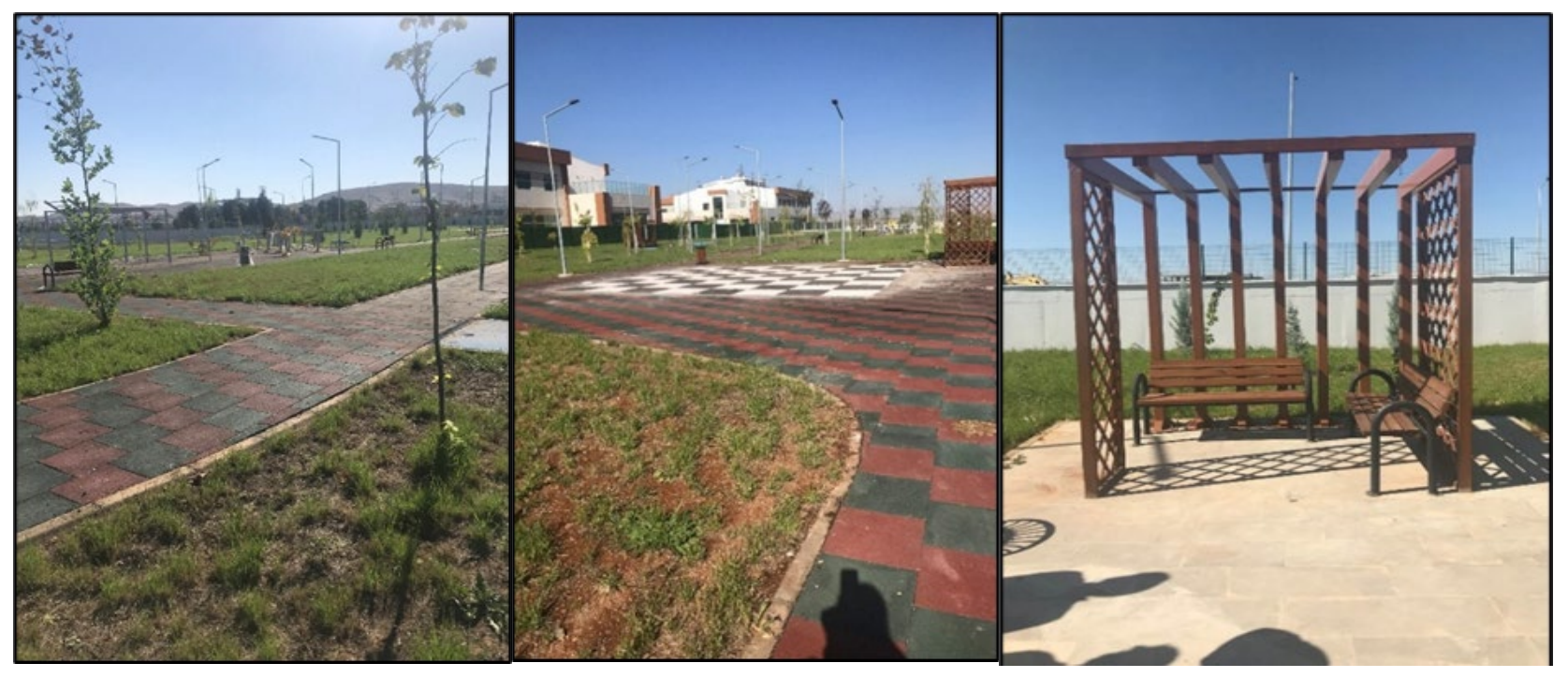

Şekil 5. Spor aletleri, yer satranc1 ve pergola (Orijinal, 2019)

AMATEM ve ÇEMATEM aynı kampüste iki ayrı bina olarak konumlandırılmıştır. 2018 tarihli ilk projede, iki bina arasında süs havuzu ve tali girişten itibaren ön ve arka bahçeyi birbirine bağlayan bir yol bulunmaktadır (Şekil 6). Yapılan görüşmeler sonucunda 2019 yılında AMATEM ve ÇEMATEM kampüsü peyzaj projesi üzerinde değişiklikler yapılmıştır. Binaların inşaatı devam ederken görüşülen AMATEM ve ÇEMATEM yöneticileri, psikiyatrist ve psikologlar, binaların kendine ait ve birbirinden bağımsız alanlarda yer almasının güvenlik nedeniyle zorunlu olduğunu belirtmişlerdir. Ancak binaların inşaatı başladığı ve ayrı kampüs olarak yeniden tasarlamak mümkün olamayacağı için en azından iki binayı birbirinden ayıran bir duvar olması gerektiği yönünde fikir belirtmişlerdir. Fakat binaların kampüs içindeki konumu ve binalar arasındaki mesafe nedeniyle peyzaj tasarımında bu iki çözüm önerisi de gerçekleştirilememiştir. Bu nedenle AMATEM ve ÇEMATEM binaları arasındaki bağlantıyı kesmek ve yetişkinler ile çocuk ve ergenlerin birbirine zarar vermemesi için AMATEM ve ÇEMATEM binaları arasına ayırıcı bir eleman yerleştirilmesi düşünülmüştür (Şekil 7).

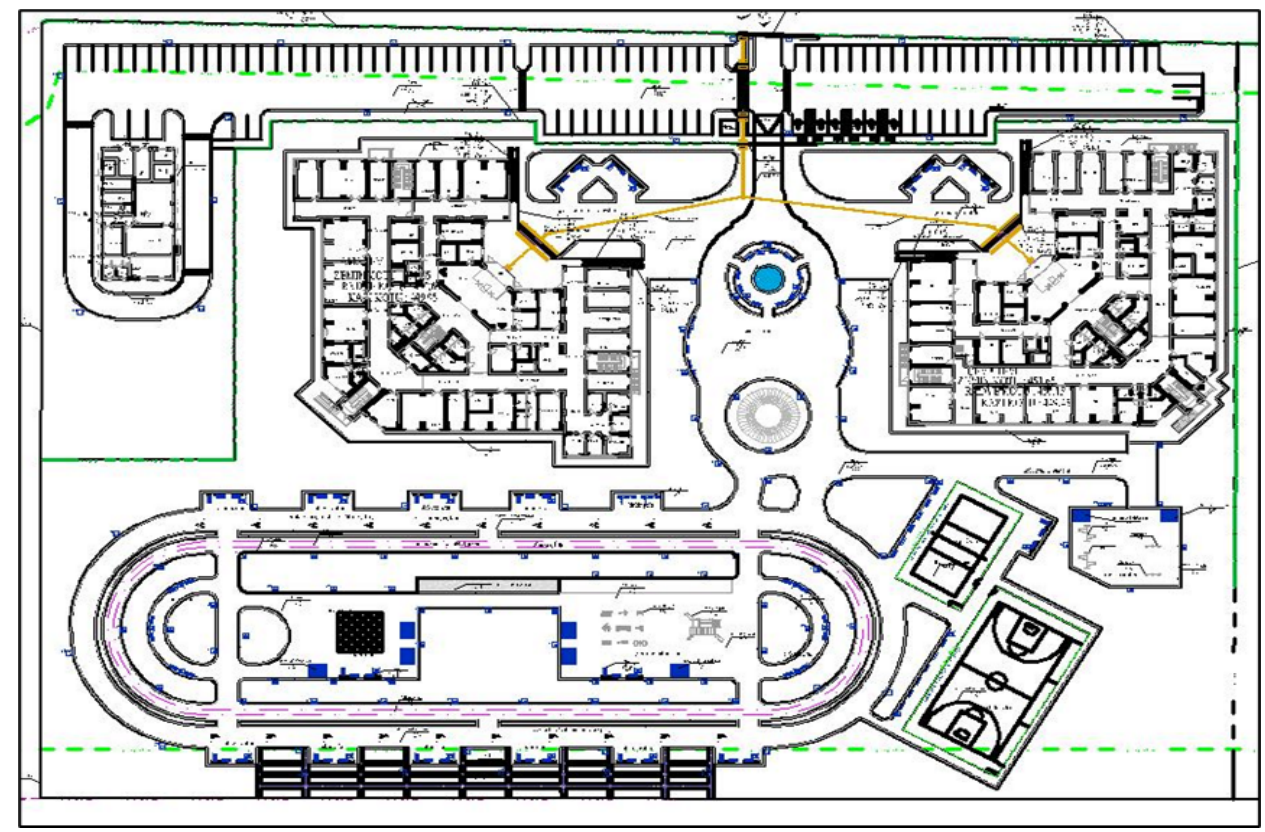

Şekil 6. AMATEM ve ÇEMATEM kampüsü ilk peyzaj projesi (Ercan, 2018)

The Effect of Landscape Design on Security Perception and Fear of Crime in Şanlıurfa AMATEM and CEMATEM Campus

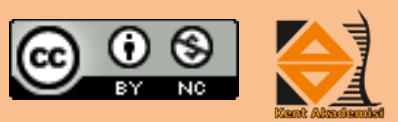


Kampüs alanına ilk erişim, kontrollü bir giriş ile otoparka yapılmaktadır (Şekil 3). Kampüsün ana giriş kısmı ve otopark, diğer açık alanlara göre dışarıya açık ve daha savunmasız pozisyondadır. Ana girişten sonra otoparktan kampüs alanına giriş, yine güvenlik kontrolünden sonra her bir binaya ayrı ayrı olacak şekilde yönlendirilmiştir (Şekil 7). Binalara erişimi ayırmak için girişten sonra T şeklinde ayırıcı bir duvar kullanılarak yeniden tasarlanmıştır (Şekil 8). Ayrıca bina girişlerinde de kontrollü giriş bulunmaktadır.

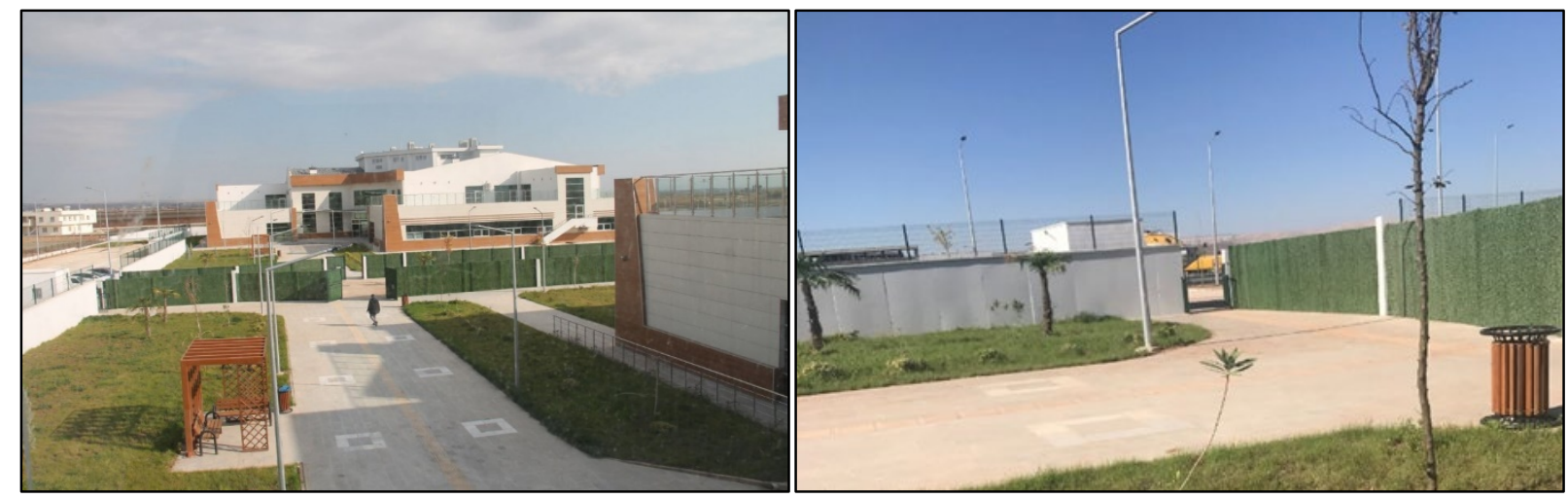

Şekil 7. AMATEM ve ÇEMATEM binaları arasındaki bağlantıyı kesen ayırıcı duvarlar (Orijinal, 2021)

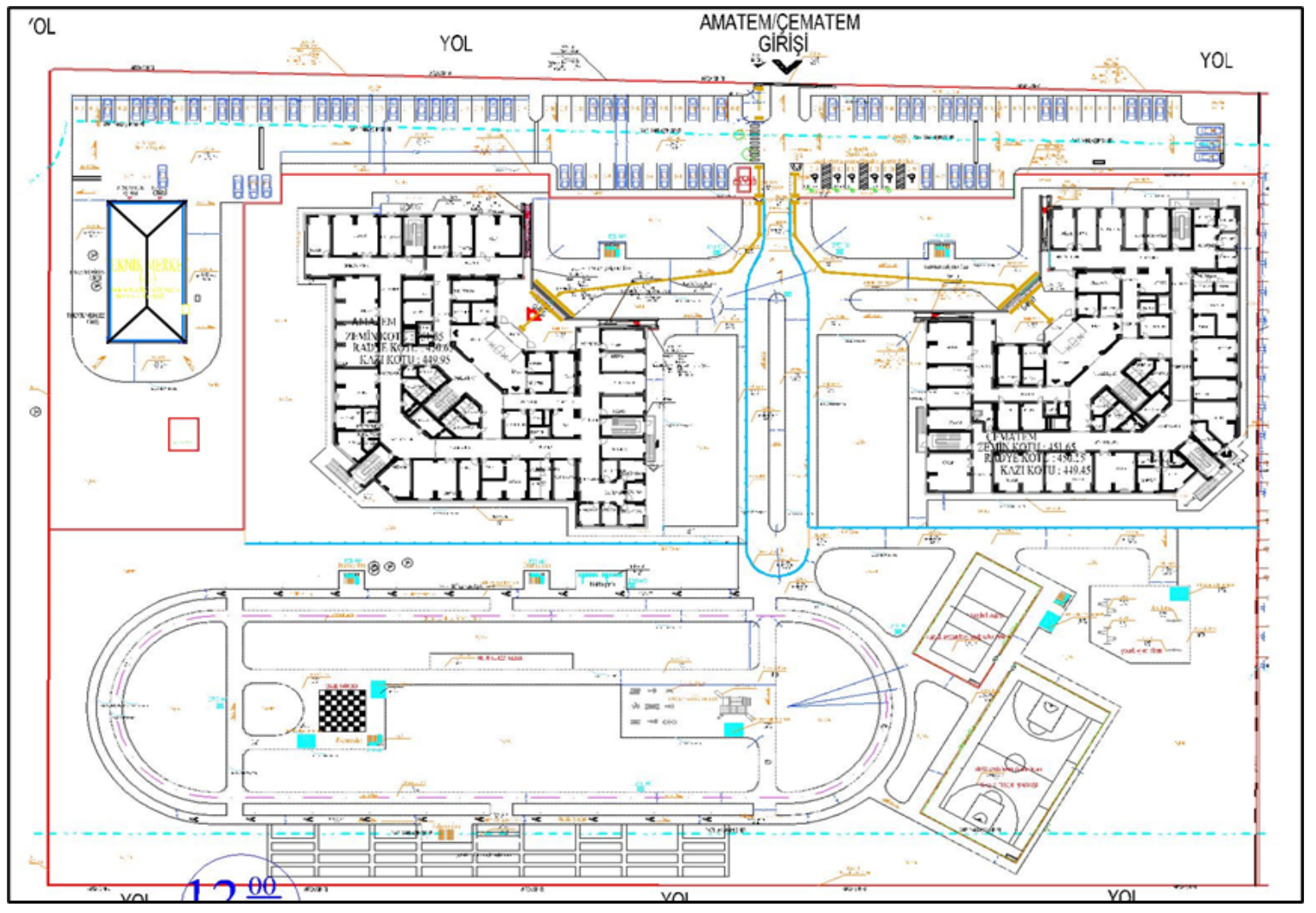

Şekil 8. AMATEM ve ÇEMATEM kampüsü revize peyzaj projesi* (Orijinal, 2019)

* Şanlıurfa AMATEM ve ÇEMATEM Kampüsü Peyzaj Projesi, Sağlık Bakanlığı, Sağlık Yatırımları Genel Müdürlüğü, Etüd Proje ve Emlak Daire Başkanlığı, Peyzaj Birim Sorumlusu Peyzaj Yüksek Mimarı Meryem Sarıkaya tarafından revize edilmiştir. 
19.12.2007 tarih ve 26735 sayılı Binaların Yangından Korunması Hakkında Yönetmelik'te binaya ulaşım yolları ile ilgili olarak "itfaiye araçlarının yaklaşabildiği son noktadan binanın dış cephesindeki herhangi bir noktasına olan yatay uzaklık en çok 45m olabilir" şeklindeki açılama nedeniyle AMATEM ve ÇEMATEM binalarına ulaşım için ayrı yol yapılamamıştır. İki bina arasındaki ortak yol form olarak değiştirilmiş, süs havuzu kaldırılmış ve yol yangın anında her iki binaya da müdahale edecek şeklide acil kullanıma uygun hale getirilmiş̧ir. Bu kısım, ayırıcı duvarlarla çevrili bir avlu şeklini almıştır (Şekil 9).

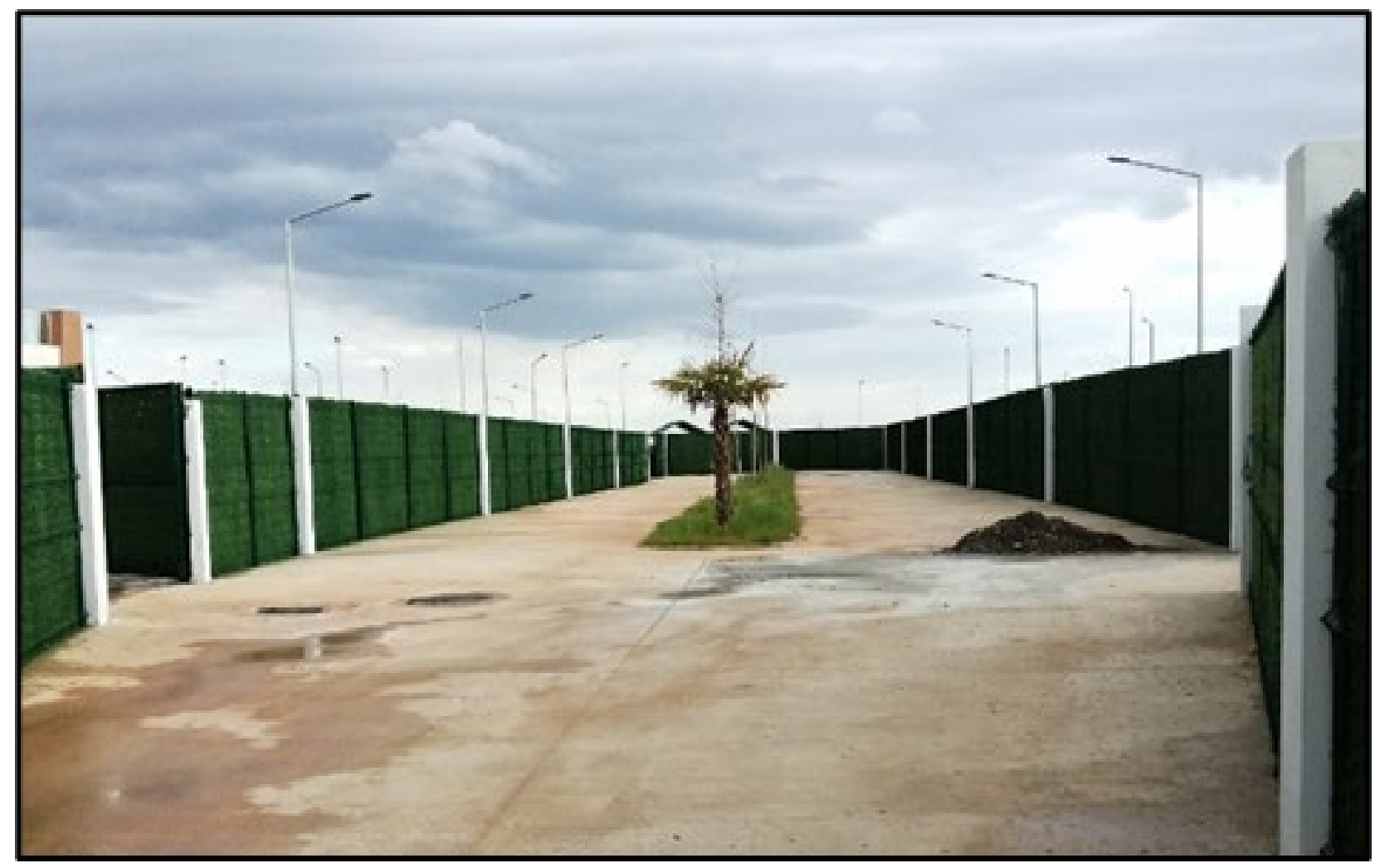

Şekil 9. Ayırıcı duvarlarla ortaya çıkan avlu (Orijinal, 2021)

\section{ŞANLIURFA AMATEM VE ÇEMATEM KAMPÜSLERINDE PEYZAJ TASARIMININ GÜVENLIK ALGISI VE SUÇ KORKUSUNA ETKİLERI:}

Güvenlik kaygıları, suç ve suç korkusu, bütün kentsel açık-yeşil alanlar için geçerlidir. Ancak AMATEM ve ÇEMATEM'de tedavi gören hastalar, alkol ve madde bağımlısı oldukları için güvenlik kaygısını ve suç ihtimalini arttıran bir durum söz konusudur. Çünkü yapılan çalışmalar, kullanılan alkol ve madde etkisiyle, tedavi esnasında da hastaların suça eğilimli olabileceğini göstermektedir. Bu durum hem hastalar hem de çalışanlar açısından önemli bir sorun oluşturmaktadır.

Bir mekânda hissedilen suç korkusu, kullanıcılarda güvensizlik algısı yaratmaktadır. Ayrıca güvensizlik algısı ve suç korkusu arasında çift yönlü bir ilişki vardır. Bu nedenle güvensizlik algısı yaratan ve suç korkusuna neden olan faktörler aynı olabilir.

\section{Şanlıurfa AMATEM ve CEMATEM kampüsünde güvenlik algısını destekleyen uygulamalar:}

Sınırların tanımlanması: Kampüste kontrolü sağlamak için sınırların duvarlarla çevrilmesi güvenlik algısı için en etkili uygulamadır. Sınırların, açık-yeşil alanın içinden ve dışından bakıldığında görüşü engellemeyecek şekilde olması 
güvenlik açısından en uygun çözümdür (Çelik, 2018). Ancak AMATEM ve ÇEMATEM kampüsü için duvarların yüksek olmasi gerekmektedir.

Binaların birbirinden ayrı konumlandırılması: AMATEM ve ÇEMATEM binalarını aynı kampüste ayrı bina olarak konumlandırılması güvenlik açısından en önemli uygulamadır. Yetişkin, çocuk ve ergen hasta gruplarının birbirleri için tehlike yaratmaması açısından binalar, ayırıcı duvarlar ile birbirinden ayrılmıştır.

Anlaşııır ve karışı olmayan peyzaj tasarımı: Spor alanı, oturma alanı, hobi bahçesi gibi mekânların bir düzen içinde yerleştirilmesi, işlevlerinin net ve belirgin olması hasta grupları için mekânın anlaşılırlığını arttırmaktadır.

Açık alanlardaki kullanımların konumlandırılması ve birbirinden ayrılması: Yürüyüş ve bisiklet yolu, kum havuzu ve atlama havuzu gibi işlevlerin birbirinden ayrı konumlandırılması hastaların ve çalışanların rahat kullanımını ve birbirine zarar vermesini önleyecektir.

Kontrollü ve iki aşamalı giriş-çıkış: Ana giriş ve tali girişte kontrol yapılması, AMATEM ve ÇEMATEM binalarına veya açık alana doğru yapılan hareketi izlemeyi kolaylaştırmaktadır. Ayrıca binalara da kontrollü giriş-çıkış yapılması, bina içindeki hareketleri izlemeyi de etkili hale getirmektedir. Böylece giriş-çıkış kontrolü, açık alan ve kapalı alanlar üzerindeki hâkimiyeti ve gerektiğinde hızlı müdahale etmeyi sağlayacaktır.

Güvenlik kameraları ve özel güvenlik personelinin varlığı: Kontrollü giriş-çıkış, özel güvenlik elemanları, güvenlik kameraları, ücretli giriş veya turnike sistemi gibi farklı alternatiflerle sağlanabilir (Çelik, 2018). Güvenlik kameralarının ve özel güvenlik personelinin varlığı, özellikle hastane personeli için güvenlik algısını arttıran bir uygulamadır.

Otopark ve yeşil alanlarda yeterli aydınlatma: Karanlık, loş ve iyi görülemeyen alanlar hemen hemen herkes için korkutucudur. Genellikle güvenliği sağlamak için tasarımda en çok tercih edilen çözüm, aydınlatmanın yeterli düzeyde olmasını sağlamaktır (Anonim, 2008). Kampüste özellikle karanlıkta görünürlüğü sağlamak için otopark ve yeşil alanlarda yapılan aydınlatma, güvenlik kameralarıyla ve gözle izlemeyi kolaylaştırmaktadır.

Geniş görüş açısı sağlayan ön ve arka bahçe: Açık-yeşil alanları kullanan insanların çevresinde diğer kullanıcıları görmesi güvenlik algılarını belirgin bir şekilde artırmaktadır. Geniş ve net görüş açıları kullanıcıların, tehdit olarak algılayabilecekleri kişilerin varlığını algılamayı kolaylaştırmaktadır (Anonim, 2008). Gerek hastalar gerekse personel için bahçede iken çevreyi net olarak görebilmesi güvenlik algısını arttırmaktadır.

Gizli alan oluşturmayan ama kısmen mahremiyet sağlayan bitkisel tasarım: Kampüste sade bir bitkisel tasarımla birlikte yeterli aydınlatma, güvenlik algısına etkili bir çözüm olmuştur. Bitkiler zamanla büyüse bile kampüste saklanma alanı ve kör noktalar oluşturmayacaktır.

Donatı elemanları ve çocuk oyun elemanları: Kentsel açık-yeşil alanlarda güvenlik sadece suç tehdidi ve tehlikesiyle ilgili değildir. Aynı zamanda kullanılan malzemeler (plastik, ahşap, metal, taş vb.), niteliği (kaygan, batıcı, kesici olması), bitkiler (zehirli ve dikenli olmayan), donatı elemanları ve çocuk oyun elemanlarının kullanıcının bedensel sağlığını ve bütünlüğünü bozmayacak nitelikte olması gerekmektedir (Çelik, 2018). Kampüste kullanılan donatı elemanları ve çocuk oyun elemanlarının kullanılan malzeme ve bu malzemenin sağlamlı̆̆ açısından kullanıcıların fiziksel güvenliği ve sağlığı açısından tehlike oluşturmayacak şekilde olması tercih edilmiştir.

Bakım çalışmalarının düzenli yapılması: Yapılan araştırmaların büyük bir kısmı, bakım, onarım ve yenileme çalışmalarının suçu önlemede ve güvenlik algısını arttırmada etkili olduğunu vurgulamaktadır. Bir yerin bakımlı ve düzenli olması, bireyleri suç işlemekten alıkoymaktadır.

\section{Sanlıurfa AMATEM ve CEMATEM kampüsünde suç korkusunu azaltan uygulamalar:}

- Hem kampüs hem de binalara giriş-çıkışların kontrollü olması, hastaların kaçmasını ve dışarıdan izinsiz girişleri önlemekte etkilidir.

- Kampüsü sınırlayan 3m'lik yüksek duvarlar olması, hastaların dışarıdan alkol ve madde teminini ciddi oranda azaltmaktadır. 
- Güvenlik kameraları ve güvenlik merkezi ile kampüs sürekli izlenmektedir. Yapılan çalışmalar, güvenlik kameraları ve özel güvenlik personelinin varlığının suça eğilimi azalttığını ortaya koymaktadır.

- Kampüste yapılan yeterli aydınlatmayla, açık görüş sağlayan alanlar oluşturulduğu için etkili bir suç kontrolü sağlanabilir.

- Kampüsün yer aldığı alanının topoğrafik açıdan genel olarak düz bir arazi üzerinde bulunması, suça firsat oluşturan gizlenme alanları ve kör noktalar oluşmasını engellemektedir.

- Kullanılan bitkilerin seyrek yerleştirilmesi, bu bitkilerin ilerleyen yıllarda gelişmesine rağmen kampüste karanlık ve loş yerler, kör noktalar ve güvensiz alanlar oluşumunu önleyecektir. Böylece suç eylemlerinin oluşmasına imkan sağlayan alanlar oluşmayacak ve kullanıcılar için suç korkusundan uzak, güvenli bir kampüs olacaktır.

- AMATEM ve ÇEMATEM binaları arasında yer alan 3m'lik yapay çim çit sistemi her iki binaya da bağımsız bahçe seçeneği sunmaktadır.

- Spor sahaları ve oyun alanları, ÇEMATEM ve AMATEM hastaları tarafindan farklı zamanlarda kullanılmaktadır.

Şanlıurfa AMATEM ve ÇEMATEM kampüsünde güvenlik algısı ve suç korkusu açısından eksik olan uygulamalar:

- Şanlıurfa AMATEM ve ÇEMATEM binaları için birbirinden bağımsız giriş,

- Her bina için ayrı otopark,

- Projenin revize edilmesiyle alınan önlemlere rağmen Şanlıurfa AMATEM ve ÇEMATEM'de tedavi gören yetişkin ile çocuk ve ergenler için ortak kullanım olarak tasarlanmış dış mekânlar, güvenlik kaygısı nedeniyle görevli eşliğinde, farklı saat ve günlerde kullanıma açılmaktadır.

- Projenin uygulama aşamasında uzmanlar tarafindan güvenlik açısından eksiklikler bildirilmiştir. Yapılan değişikliklere rağmen kampüs kullanıldıkça gerek hastalar gerekse çalışanlar için tasarım aşamasında yer verilmeyen eksiklikler ve ihtiyaçların ortaya çıkması olasıdır.

- Ayrıca bu merkezlerde çalışanları hastalardan koruyacak tedbirlere de ihtiyaç duyulmaktadır.

- Ahşap işleri, resim ve müzik faaliyetleri için ilgili branşlardan uzmanlar eğitim vermektedir. Ancak hobi bahçesi ve bahçede yapılacak faaliyetler için her hangi bir uzman desteği yoktur. Hastalar bahçede serbest, programsız ve amaçsız hareket etmektedir. Bu durum ise tedavi gören hastalar için alkol ve madde yoksunluğunu hatırlatıcı etki yapacaktır.

- Bahçenin iyileşme için katkı sağlayacak nitelikleri yeterli değildir. Bağımlılık tedavisi gören hastaların bir program doğrultusunda bahçede birtakım işlere dahil edilmesi, hobi ve uğraş edinmelerini sağlayarak tedavi esnasında ve normal yaşama döndükten sonra suça eğilimini azaltmaktadır.

Yapılan araştırmalar, alkol ve madde bağımlılı̆̆ tedavi sürecinde, bahçenin ve bahçede yapılan faaliyetlerin tıbbi tedavi, psiko-sosyal tedavi ve sosyal rehabilitasyonu önemli ölçüde desteklediğini göstermiştir. Özellikle alkol ve madde bağımlılığı tedavisi gören bireylerde, alkol ve madde kullanımının sonlanmasıyla ortaya çıkan boşluğun-yoksunluğun yerinin bahçede yapılan çeşitli faaliyetlerle doldurularak bağımlılı̆ıı ortadan kaldırılması sağlanmaktadır. Ancak Türkiye'de AMATEM ve ÇEMATEM gibi merkezlerin yanı sıra diğer sağlık merkezlerinde de bahçenin ve bahçede yapılan faaliyetlerin tedavi sürecine dahil edilmediği görülmektedir.

Alkol veya madde bağımlılığı tedavisi gören bireyler için iyileştirme bahçesi:

Sosyalleşme becerilerini geliştirir: Birçok bağımlı, insanlarla nasıl iletişim kuracağı konusunda sorunlar yaşamaktadır. Tedavi gören bağımlılar bahçede çalışırken, diğer bağımlılar ve bahçıvanlarla iletişime geçerek sosyalleşebilirler.

Egzersiz olanağı sağlar: Bağımlıların iyileşmesi için egzersiz yapmak çok önemlidir. Bahçede çalışmak, esneme, germe ve kaldırma gibi hafif veya yorucu fiziksel aktivite yapma imkânı sunar. Ayrıca bahçede spor alanı ve spor aletleri olması, fiziksel aktiviteyi arttırmak için daha da etkilidir.

Güneş ışığına maruz kalma: D vitamini, güneşe ışınlarına maruz kalındığında vücut tarafından doğal yollardan üretir. $\mathrm{Bu}$ temel besin, sağliksız bir yaşam süren bağımlılarda genellikle eksiktir. Bahçede çeşitli işlerle uğraşırken güneş 1şı̆̆ına maruz kalmak vücudun daha fazla D vitamini üretmesine yardımcı olur ve iyileşmekte olan bağımlı kendini daha enerjik ve zihinsel olarak uyanık hissedecektir. 
Anksiyeteyi azaltır: Bahçede çalışmak keyifli bir aktivitedir ve iyileşmekte olan bir bağımlının kaygı düzeyini azaltabilir. Geri çekilme semptomları yaşayan herkes kendini gergin hisseder ancak doğa ile iç içe olmak; bir amaç uğruna (çiçek, sebze ve meyve yetiştirmek için) çalışmak tedavi edicidir (Lang, 2019).

Özgüveni ve özsaygıyı artırır: Rehabilitasyon merkezindeki bireylerin, bahçede çalışarak kendi emek ve çabalarıyla bahçenin güzelleşmesine şahit olması, bahçeden çiçek, sebze ve meyve gibi ürün elde etmesi hastaların işe yarama duygusu ile birlikte kendilerine güvenmelerine yardımcı olur. Bu, bireydeki benlik saygısının geliştirmesine yardımcı olabilir.

Konsantrasyon düzeylerini artırır: Rehabilitasyon merkezinde güzel bir bahçe yapmak, hastaların ekim-dikim, çapalama, sulama, yabani ot toplama, gübreleme gibi yıl boyu düzenli yapılması gereken işlere odaklanmasıyla mümkündür. $\mathrm{Bu}$, bir rehabilitasyon merkezinden ayrıldıktan sonra okula dönebilmeleri veya iş bulabilmeleri için iyileşen bağımlıların konsantrasyon düzeylerini artırmanın yararlı bir yolu olabilir (Lang, 2019).

Öfkeyi serbest bırakmayı sağlar: Bahçede çalışmak öfke duygularının serbest kalmasına yardımcı olabilir. Bahçe işlerine odaklanmak, bir bağımlının bağımlılıklarıyla ilgili olarak kendisine ve başkasına karşı hissettiği öfke duygularını gidermesine yardımcı olabilir.

Uyku kalitesini iyileştirir: Açık havada bulunmak ve çeşitli işlerle uğraşmak fiziksel yorgunluk ve zihinsel rahatlamanın beraberinde hastaların iyi bir uyku uyumasını sağlar.

Her gün bir amaç sağlar: Bahçede düzenli yapılması gereken işlerin takibini yapmak ve sorumluluk almak hastalar için bir amaç oluşturur. Tedavi gören bağımlının bir amaca sahip olması, hayatta kalmak, fiziksel ve psikolojik sağlığı için önemli katkılar sağlar.

Depresyonun üstesinden gelir: İyileşme sürecindeki çoğu bağımlı, depresyon yaşar ve bahçede vakit geçirmek ve çeşitli işleri yapmak, ilaç tedavisiyle birlikte iyileşmeye yardımcı olur.

Bir beceri kazandırır: Bakım işlemlerini, çiçek, meyve ve sebze yetiştirmeyi yaparak öğrenmek mesleki bir beceri kazandırır. Böylece hastaların tedavi sürecinden sonra normal yaşama uyum ve yaşamları üzerindeki kontrollerini sağlamaya yardımcı olur (Lang, 2019).

\section{SONUÇ VE ÖNERILLER:}

Şanlıurfa AMATEM ve ÇEMATEM Kampüsü’nde fiziksel çevrenin güvenlik algısı ve suç korkusuna etkisinin belirlenmesi hem çalışanlar hem de hastalar ve hasta yakınları açısından oldukça önemlidir. Kullanıcıların güvenlik algısı ve suç korkusunu anlamak, kampüste güvenliğinin sağlanması ve etkili önlemlerin alınması için önem arz etmektedir.

30710 sayılı Bağımlılık Danışma, Arındırma ve Rehabilitasyon Merkezleri Hakkında Yönetmelik incelendiğinde; "genel fiziki özellikler" kapsamında bina içinde olması gereken hasta odası, poliklinik muayene odası, hasta/danışan görüşme odası, bekleme salonu, grup terapi ve eğitim odası, yaşam alanı ve iş uğraş atölyesi birimleri hakkında detaylı açıklamaların yer aldığı görülmektedir. "Türüne göre fiziki özellikler" kapsamında ise "ayakta rehabilitasyon merkezleri" ile "yataklı rehabilitasyon merkezleri” için mimari birimler dışında dış mekânla ilgili olarak:

- "Ayakta rehabilitasyon merkezlerinde ... Bina içinde veya dışında, hastaların en az iki farklı dalda spor yapmasına imkân sağlayan gerekli ekipmana sahip spor alanı bulunur."

- "Yataklı rehabilitasyon merkezlerinde, ... bina dışında hastaların spor yapabileceği birden fazla etkinlik alanı için en az $100 \mathrm{~m}^{2}$, hobi bahçesi gibi aktiviteler için de en az $100 \mathrm{~m}^{2}$ olacak şekilde toplam $200 \mathrm{~m}^{2}$ alan ayrılır."

Şeklinde açıklama yer almaktadır. Ancak bu açıklamalar, kampüs veya bahçenin nasıl olması gerektiği ve hatta bahçenin iyileşme için katkı sağlayacak niteliklerini ortaya koyacak açıklamalar değildir.

Alkol ve madde bağımlılığı farklı risk faktörlerinin karmaşık etkileşimi sonucu oluşan bir davranış sorunu olduğu için sadece tıbbi müdahaleyle beklenen değişimi sağlamak mümkün değildir. Kişinin alkol ve madde kullanmayı bırakarak yeniden işlevsel bir birey haline gelebilmesi için tedavi sırasında ve sonrasında içinde bulunduğu sosyal koşulların da 
ele alınması gerekmektedir. Özellikle alkol ve madde kullanımını bırakmanın oluşturduğu boşluğu dolduracak iş, uğraşı ve faaliyetleri organize etmek, yeni beceriler kazandırmak, işlevsel sosyal ortamlar oluşturmak için sosyal tedavi programlarına ihtiyaç duyulmaktadır (Karataş, 2021).

Alkol veya madde bağımlılı̆̆ının üstesinden gelmeye çalışan bireyler için iyileşme sürecinde tıbbi tedavi, arınma ve psikoterapinin yanı sıra farklı terapi yöntemleri de vardır. Bunlardan biri de bahçecilik terapisi olup alkol ve madde kullanımını bırakmanın oluşturduğu boşluğu bahçede yapılan çeșitli faaliyetlerle doldurarak bağımlıların iyileșmesini desteklemektedir. Maalesef Türkiye'de farklı nitelikteki sağlık kurumlarında, iyileştirme bahçeleri çok kısıtlı olarak tedaviyi destekleyici şekilde kullanılmaktadır.

Bu çalışmadan yola çıkarak:

- Yönetmeliklerde binalar için olduğu gibi hastane ve rehabilitasyon merkezi bahçeleri için de açıklayıcı bilgiler ve mekânsal standartlara yer verilmesi,

- Mevcut alkol ve madde bağımlılığı rehabilitasyon merkezleri kampüslerinde yapılacak değişikliklerle bahçenin ve bahçede yapılacak faaliyetlerin de tedavi sürecine dahil edilmesi,

- Tablo 1'de yer alan yakın zamanda ve gelecekte planlanan AMATEM ve ÇEMATEM projeleri için tedavinin bahçede yapılacak çeşitli faaliyetlerle desteklenecek şekilde tasarlanması,

- Bahçede yapılacak faaliyetler (oyun, spor faaliyetleri ve bahçe işleri gibi etkinlikler) için uzman görevlendirilmesi, bahçede bir program ve amaç doğrultusunda faaliyetlerin yapılması,

- AMATEM ve ÇEMATEM gibi merkezlerin peyzaj tasarımının kentsel yeşil alan tasarım deneyimi ile yapılması mümkün değildir. Bu tür özel alanlar için genel tasarım çözümleri yeterli olmayacaktır. Tasarımı aşamasında psikolojik danışman ve rehber, sosyal hizmet uzmanı ile psikolog, psikiyatrist, hemşire gibi sağlık çalışanlarından fikir alınması gerekmektedir. Hem güvenlik algısını arttırmak ve suç korkusunu azaltmak hem de özel ihtiyaçlar ve durumlara sahip bu merkezler için "Tasarım Rehberi” hazırlanması önerilebilir.

\section{Etik Standart ile Uyumluluk}

Çıkar Çatışması: Yazarlar herhangi bir çıkar çatışmasının olmadığını beyan eder.

Etik Kurul İzni: Bu çalışma için etik kurul iznine gerek yoktur.

\section{KAYNAKÇA}
Anonim,
(1982).
Yatakl1
Tedavi
Kurumlar1
İşletme
Yönetmeliği,

https://www.mevzuat.gov.tr/MevzuatMetin/3.5.85319.pdf, Erişim tarihi: 30.06.2021.

Anonim, (2008). What role can design play in creating safer parks?, https://www.pps.org/reference/what-role-candesign-play-in-creating-safer-parks/, Erişim tarihi: 04.08.2021.

Anonim, (2018). On Birinci Kalkınma Planı (2019-2023), Sağlıklı Yaşam ve Bağımlılıkla Mücadele Çalışma Grubu, Bağımlılıkla Mücadele Alt Çalı̧̧ma Grubu Raporu, Ankara.

Anonim, (2019). Bağımlılık Danışma, Arındırma ve Rehabilitasyon Merkezleri Hakkında Yönetmelik, https://www.resmigazete.gov.tr/eskiler/2019/03/20190310-2.htm, Erişim tarihi: 28.07.2021.

Anonim, (2021). Amatem ve Çematem Projeleri, https://sygm.saglik.gov.tr/TR,30892/amatem-ve-cematemprojeleri.html, Erişim tarihi: 15.07.2021.

Anonim, (2021a). AMATEM, http://www.amatem.org/amatem/amatem-nedir/, Erişim tarihi: 17.07.2021.

Arabacı, L. B., Taş, G., Dikeç, G. (2017). Çocuk ve Ergenlerde Madde Kullanımı, Suça Yönelme, Ruhsal Bozukluklar ve Hemşirelik Bakımı, Bağımlılık Dergisi-Journal of Dependence, 18(4), 135-144.

Çelik, F. (2018). Kentsel Açık-Yeşil Alanlarda Güvenlik. İdealkent, 23(9), 58-94. 
Çelik, F. ve Mirza, E. (2020). Öğrencilerin Selçuk Üniversitesi, Alaeddin Keykubad Kampüsü'ne Yönelik Suç Korkusu. İnönü Üniversitesi Sanat ve Tasarım Dergisi, 10(22), 1-21.

Dolu, O., Uludağ, Ş. ve Doğutaş, C. (2010). Suç Korkusu: Nedenleri, Sonuçları ve Güvenlik Politikaları İlişkisi, Ankara Üniversitesi SBF Dergisi, 65 (1), 57-81.

Ercan, A. (2018). Şanlıurfa Amatem ve Çematem Kampüsü Peyzaj Uygulama Projesi, Dörtboyut Proje, Ankara.

Giddens, A., Sutton, P. W. (2019). Sosyoloji. İstanbul: Kırmızı Yayınları.

Karakartal, D. (2020). Uyuşturucu Madde Bağımlılı̆̆ı ve Suç İlişkisi, Uluslararası Beşerî Bilimler ve Eğitim Dergisi (IJHE), 6(14), 614-623.

Karakaya, O. (2015). Liseli Gençlerde Suç Mağduru Olma Korkusu: Ankara Örneği. Hacettepe Üniversitesi Sosyal Bilimler Enstitüsü Sosyoloji Anabilim Dalı, Yüksek Lisans Tezi, Ankara.

Karataş, Z. (2021). Madde Bağımlılığının Nedenlerine, Sosyal Tedavi ve Rehabilitasyonuna İlişkin Görüşlerin Odak Grup Yöntemiyle Belirlenmesi, Türkiye Sosyal Araştırmalar Dergisi, 1, 67-94.

Karatoprak, S. ve Uzun, N. (2020). Çocuk ve Ergen Madde Tedavi Merkezinde Yatarak Tedavi Gören Ergenlerin Sosyodemografik ve Klinik Değerlendirilmesi, Turk J Child Adolesc Ment Health, 27(2), 110-115.

Lang, P. (2019). The Benefits of Gardening Therapy in Addiction Recovery, https://www.bigblogofgardening.com/benefits-gardening-therapy-addiction-recovery/, Erişim tarihi: 05.08.2021.

Özaşçllar, M. Ö. ve Ziyalar, N. (2009). Suç Korkusu: İstanbul'da Yaşayan 18-25 Yaş Grubu Üniversite Öğrencilerin Mağdur Olma Riskleri Hakkındaki Görüşlerin Değerlendirilmesi. Adli Bilimler Dergisi, 8(1), 7-17.

Tomanbay, İ. (2016). Madde Bağımlılığı ve Sosyal Hizmet, İstanbul Üniversitesi Açık ve Uzaktan Eğitim Fakültesi, Sosyal Hizmetler Lisans Tamamlama Programı Ders Kitabı, İstanbul.

Uludağ, Ş. (2010). Vatandaşların Suç Korku (Güvenlik Endişesi) Seviyesine Etki Eden Faktörler ve Alınabilecek Önlemler: Malatya Örneği, Polis Bilimleri Dergisi, 12(1), 1-28.

Uygun, E. (2018). Şanlıurfa Amatem ve Çematem Kampüsü Mimari Uygulama Projesi, Uygun Mimarlık, Ankara

Yoldaş, C. ve Demircioğlu, H. (2020). Madde Kullanımı ve Bağımlılı̆̆ını Önlemeye Yönelik Psikoeğitim Programlarının İncelenmesi, Bağımlılık Dergisi-Journal of Dependence, 21(1), 72-91.

The Effect of Landscape Design on Security Perception and Fear of Crime in Şanlıurfa AMATEM and CEMATEM Campus 